\title{
Qualitative characteristics of the Longissimus thoracic lumborum muscle of Nellore cattle during different maturation periods
}

\section{Características qualitativas do Longissimus thoracic lumborum de bovinos Nelore maturado por diferentes períodos}

\author{
Juliana Santos Farias ${ }^{1 *}$; Francisco de Assis Fonseca de Macedo ${ }^{2}$; Gladston Rafael \\ de Arruda Santos ${ }^{2}$; Leandro Teixeira Barbosa ${ }^{2}$; Ana Andréia Teixeira Barbosa ${ }^{3}$; \\ Fernanda Losi Alves de Almeida ${ }^{4}$, Natalia Holtz Alves Pedroso Mora ${ }^{4}$
}

\begin{abstract}
The effect of maturation on the physical ( $\mathrm{pH}$, color, weight loss on cooking, and shear force) and biological (microbiology, concerning mesophiles and psychrotrophiles, and sarcomere length) characteristics of the Longissimus thoracic lumborum muscle of adult Nellore cattle was assessed over four maturation periods $(0,7,14$, and 21 days) and two cut thicknesses $(2.5$ and $7.5 \mathrm{~cm})$. Sixty-four Longissimus thoracic lumborum muscles from castrated Nellore males were purchased from Frigorífico Nutrial, Sergipe, Brazil. The study was performed using a completely randomized design, corresponding to a $2 \times 4$ factorial with eight replicates. The microbiological analysis revealed the sanitary conditions in which the samples were handled and stored, yielding counts of psychrotrophiles $\left(2.18 \times 10^{5} \mathrm{CFU}\right.$ $\left.\mathrm{g}^{-1}\right)$ and mesophiles $\left(2.4 \times 10^{5} \mathrm{CFU} \mathrm{g}^{-1}\right)$ well below the critical deterioration level $\left(10^{6} \mathrm{CFU} \mathrm{g}^{-1}\right)$. The $\mathrm{pH}(5.57)$ and the loss on cooking (24.13\%) were not influenced by the evaluated variables $(\mathrm{P}>0.05)$. The other evaluated parameters significantly varied as a function of the maturation period and the cut thickness (both $\mathrm{P}<0.05$ ). Meat luminosity varied with both the cut thickness and maturation period. The 2.5 -cm-thick cut matured for 14 days and the 7.5 -cm-thick cut matured for 21 days were darker than the 2.5 -cm-thick cut matured for 7 days and the 7.5 -cm-thick cut matured for 14 days, which were the lighter-colored samples (similar to non-matured meat). The intensity of the red color of the meat was different beginning after 14 days of maturation in the 7.5 -cm cuts $(\mathrm{P}<0.05)$ but differences were not evident in any of the 2.5 -cm cuts $(\mathrm{P}>0.05)$. Regarding the $\mathrm{b}^{*}$ intensity, the 2.5 -cm cut yielded a darker staining at time zero, which decreased with the maturation period. However, the $7.5-\mathrm{cm}$ cut differed between the non-matured and the matured samples. Regarding the red and yellow color of the meat fat ( $\mathrm{a}^{*}$ and $\mathrm{b}^{*}$, respectively), $\mathrm{a}^{*}$ displayed lighter intensity at 7 days of maturation or the $2.5-\mathrm{cm}$ cut $(\mathrm{P}<0.05)$, while the intensity of $\mathrm{b}^{*}$ was similar from 7 days of maturation onwards for both cuts $(\mathrm{P}>$ $0.05)$. The shear force of the meat decreased to $4.49 \mathrm{kgf}$ at 21 days of maturation. The sarcomere length varied for the $2.5-\mathrm{cm}$ cut $(\mathrm{P}<0.05)$ but not for the $7.5-\mathrm{cm}$ cut, which remained constant $(\mathrm{P}>0.05)$. Longissimus thoracic lumborum muscle of adult Nellore cattle should be matured as a larger, vacuumpacked cut for a minimum of 14 days to produce meat with improved quality.
\end{abstract}

Key words: Sirloin. Color. Thickness. Tenderness. Sarcomere. Texture.

1 M.e, em Zootecnia, Universidade Federal de Sergipe, UFS, São Cristóvão, SE, Brasil. E-mail: julianafarias_s@yahoo.com

2 Profs. Drs., Departamento de Zootecnia, UFS, São Cristóvão, SE, Brasil. E-mail: fafmacedo@uem.br; gladstonrafael@yahoo. com.br; leandro35441@yahoo.com.br

3 Prof ${ }^{a}$ Dr $^{\mathrm{a}}$, Departamento de Bacteriologia, UFS, São Cristóvão, SE, Brasil. E-mail: ana.barbosaufs@yahoo.com.br

$4 \operatorname{Prof}^{\text {as }}$ Dr $^{\text {as }}$, Departamento de Histologia, Universidade Estadual de Maringá, UEM, Maringá, PR, Brasil. E-mail: flaalmeidauem@ gmail.com; natalia-mora@hotmail.com

* Autor for correspondence

Received: June 20, 2017 - Approved: Jan. 09, 2018 


\section{Resumo}

$\mathrm{O}$ efeito da maturação nas características físicas $(\mathrm{pH}$, cor, perda de peso na cozedura e força de cisalhamento) e biológico (microbiologia, no que se refere aos mesófilos e psicrotrófilos e comprimento do sarcômero) do músculo Longissimus thoracic lumborum do gado Nelore adulto foi avaliado durante quatro períodos de maturação $(0,7,14$ e 21 dias) e duas espessuras de corte $(2,5$ e 7,5 cm). Foram adquiridos 64 músculos de Longissimus thoracic lumborum de machos castrados Nelore do Frigorífico Nutrial, Sergipe, Brasil. O estudo foi realizado utilizando um delineamento inteiramente casualizado, correspondente a um fatorial de $2 \times 4$ com oito repetições. A análise microbiológica revelou as condições sanitárias em que as amostras foram manipuladas e armazenadas, produzindo contagens de psicrotrófilos $\left(2,18 \times 10^{5} \mathrm{UFC} \mathrm{g}^{-1}\right)$ e mesófilos $\left(2,4 \times 10^{5} \mathrm{UFC}^{-1}\right)$ bem abaixo do nível crítico de deterioração $\left(10^{6} \mathrm{UFC} \mathrm{g}^{-1}\right)$. O pH $(5,57)$ e a perda no cozimento $(24,13 \%)$ não foram influenciados pelas variáveis avaliadas $(\mathrm{P}>0,05)$. Os outros parâmetros avaliados variaram significativamente em função do período de maturação e da espessura do corte (ambos $\mathrm{P}<0,05)$. A luminosidade da carne variou tanto com a espessura do corte quanto com o período de maturação. $\mathrm{O}$ corte de $2,5 \mathrm{~cm}$ de espessura maturado durante 14 dias e o corte de 7,5 cm de espessura maturado por 21 dias foi mais escuro do que o corte de $2.5 \mathrm{~cm}$ de espessura maturado por 7 dias e os 7.5 - que eram as amostras de cores mais claras (semelhantes para carne não maturada). A intensidade da cor vermelha da carne foi diferente após 14 dias de maturação nos cortes de $7,5 \mathrm{~cm}(\mathrm{P}<0,05)$, mas as diferenças não foram evidentes em nenhum dos cortes de $2,5 \mathrm{~cm}(\mathrm{P}>0,05)$. Em relação à intensidade $\mathrm{b}^{*}$, o corte de $2,5 \mathrm{~cm}$ produziu uma coloração mais escura no tempo zero, que diminuiu com o período de maturação. No entanto, o corte de $7,5 \mathrm{~cm}$ diferiu entre as amostras não maturadas e as maturadas. Em relação à cor vermelha e amarela da gordura da carne ( $\mathrm{a}^{*} \mathrm{e} \mathrm{b}^{*}$, respectivamente), $\mathrm{a}^{*}$ intensidade mais leve aos 7 dias de maturação ou corte de $2,5 \mathrm{~cm}(\mathrm{P}<0,05)$, enquanto a intensidade de $\mathrm{b}^{*}$ foi semelhante a 7 dias de maturação em ambos os cortes $(\mathrm{P}>0,05)$. A força de cisalhamento da carne diminuiu para $4,49 \mathrm{kgf}$ aos 21 dias de maturação. $\mathrm{O}$ comprimento do sarcômero variou para o corte de $2,5 \mathrm{~cm}(\mathrm{P}<0,05)$, mas não para o corte de $7,5 \mathrm{~cm}$, que permaneceu constante $(\mathrm{P}>0,05)$. O músculo Longissimus thoracic lumborum de Nelore adulto deve ser maturado por no mínimo 14 dias, à vácuo, para resultar numa carne com qualidade aprimorada. Palavras-chave: Contra filé. Cor. Espessura. Maciez. Sarcômero. Textura.

\section{Introduction}

The Nellore breed of Brazilian cattle herds comprises approximately $90 \%$ of zebu cattle (ABIEC, 2015). In Brazil, zebu cattle are predominantly bred in an extensive system that increases the age at the time of slaughter. These cattle also have lower calpain and higher calpastatin levels, which reduce meat tenderness compared to taurine cattle.

Meat quality parameters such as $\mathrm{pH}$, color, tenderness, and water retention capacity are influenced by individual intrinsic (muscle physiology, race, and age) and extrinsic factors (feed, production system, and pre-slaughter and post mortem conditions), and the interaction between these factors. Tenderness characteristics are closely related to $\mathrm{pH}$, water retention capacity, degree of fat, and connective tissue and muscle fiber characteristics. Therefore, meat quality may be undesirably altered by changes in these factors (PARDI et al., 2001).

Nellore cattle produce meat with a more intense coloration, higher $\mathrm{pH}$, and lower water losses on thawing and cooking (MAGGIONI et al., 2012). However, the same authors also considered Nellore meat to be less tender than the meat of taurine cattle, due to the lower intramuscular fat deposition, the correlation between the later slaughter age and the higher proportion of collagen in muscles, and the high calpastatin proportion.

The maturation process appears to be an effective alternative method to improve the meat of advanced 
age zebus. Maturation is a prolonged action that takes place under controlled temperature, involving the proteases that are naturally present in the meat. The process occurs over a variable period (between 7 and 28 days), yielding a meat that is more tender while avoiding the use of mechanical force and/ or chemical additives (KOOHMARAIE, 1989; KRINCHEV et al., 2013). Moreover, the maturation process exacerbates the qualitative features of beef.

The literature on maturation research is scarce regarding the thickness of commercial cuts. A2.5-cmthick cut of Longissimus thoracic lumborum muscle is the most common presentation. However, thicker commercial cuts are available. The objective of the present study was to assess the effect of maturation on the physical and biological characteristics of adult Nellore cattle sirloin meat, by comparing two cut thicknesses and four maturation periods.

\section{Materials and Methods}

Sixty-four sirloin (Longissimus thoracic lumborum) samples from the half-carcasses of Nellore cattle with six and eight permanent teeth were used. Samples were purchased from Frigorífico Nutrial Ltd., which is located $100 \mathrm{~km}$ from the capital city of Aracaju. The slaughter was approved by a federal inspector (SIF 3246/SE) and followed the RIISPOA recommendations (BRASIL, 1952).

A $12.5 \mathrm{~cm}$-long sample of the Longissimus thoracic lumborum from the left half-carcass stored for 72 hours at $4^{\circ} \mathrm{C}$ in a refrigerated chamber was collected during deboning that was done in the refrigerator. Each sample was subdivided into the evaluated cut thicknesses $(2.5$ and $7.5 \mathrm{~cm})$, with at least one extra 2.5 -cm sample collected for the zerotime evaluations. Cuts were individually vacuumpacked and immediately identified at a room temperature of $10^{\circ} \mathrm{C}$.

Samples were stored in thermal boxes and transported from the refrigerator to the meat research laboratory of the Federal University of
Sergipe, where the maturation process and some of the evaluations were carried out. Meat cuts were matured under vacuum and at a controlled temperature $\left(0-2{ }^{\circ} \mathrm{C}\right)$ using thermo-hygrometers coupled to the controlled temperature refrigerators. Samples were distributed evenly and randomly on the shelves, and were separated by days of maturation.

The packages containing Longissimus thoracic lumborum were opened after each maturation period $(0,7,14$, or 21 days $)$, and their $\mathrm{pH}$ and meat and fat colors were measured. A portion was extracted to evaluate sarcomere length and to perform the microbiological analysis. Samples with a $7.5-\mathrm{cm}$ thickness were subdivided into $2.5-\mathrm{cm}$ portions, vacuum-repackaged individually, identified, and frozen after the evaluations were performed.

For the microbiological analysis, $10 \mathrm{~g}$ of each steak was collected aseptically, individually packed in aluminum foil, identified, and sent to the microbiology laboratory of the Federal University of Sergipe. The methodology followed the microdroplet cell counting technique described by Romeiro (2001) to count psychrotrophiles and mesophiles.

The total counts of mesophilic and psychrotrophic bacteria were achieved by seeding the dilutions from each sample in pour plate agar. After solidification, the plates were incubated in an inverted position at $30^{\circ} \mathrm{C}$ for 72 hours for mesophilic and lactic acid bacteria, and at $7^{\circ} \mathrm{C}$ for 7 days for psychrotrophic bacteria, after which bacterial colonies were counted (VANDERZANT; SPLITTSTOESSER, 1992). The average counts of the drops (in triplicate) were evaluated biometrically according to CavalliSforza (1974). The dilution corresponded to the $10^{-1}$ dilution, from which the other decimal dilutions up to $10^{-5}$ were obtained. The following formula was applied for to determine the viable count:

$$
\mathrm{CFU} \mathrm{g}{ }^{-1}=(\mathrm{CFU} \times \mathrm{DF} / \text { Aliquot }) / \mathrm{SA}
$$

where CFU denotes colony forming unit, DF denotes dilution factor in $10^{\mathrm{x}}$, Aliquot denotes the 
volume of the plated sample in $\mathrm{ml}$, and SA denotes the amount of sample used in $\mathrm{g}$.

A portable $\mathrm{pH}$ meter with a skewer and an Ion Sensitive Field Effect Transistor (ISFET) sensor calibrated in buffer solution ( $\mathrm{pH} 4$ and 7) was used to measure the $\mathrm{pH}$ of each cut of meat. The $\mathrm{pH}$ meter was inserted into the same location of the muscle portion of each sample of steak, and the readout was recorded.

Color readings were recorded after each meat sample was removed from the packaging and exposed to the ambient temperature of the laboratory (approximately $19^{\circ} \mathrm{C}$ ) for at least 20 min, which allowed oxygenation of the superficial myoglobin. Meat and fat color measurements were performed using a CR10 colorimeter (Minolta). The values were expressed in the CIE system $\left(\mathrm{L}^{*}, \mathrm{a}^{*}\right.$, $b^{*}$ ), where $L^{*}$ is the luminosity, $a^{*}$ is the red color intensity, and $b^{*}$ is the yellow color intensity. Two measurements were performed at the same spot of each steak. The average $L^{*}$ values were recorded for muscle tissue, and average $a^{*}$ and $b^{*}$ values were recorded for the adipose and muscle tissues.

The evaluations of weight loss on cooking and texture were performed in the Laboratory of Animal Science of the State University of Maringá (UEM). The 2.5-cm-thick samples of each treatment were transported in a thermal box containing ice gel packs, and refrigeration was maintained until analysis. The samples were thawed for 24 hours under refrigeration temperature $\left(4^{\circ} \mathrm{C}\right)$, followed by packing in aluminum foil and weighing (initial weight, IW). Samples were roasted in a $170^{\circ} \mathrm{C}$ preheated grill until their geometric center reached a temperature of $70^{\circ} \mathrm{C}$ as measured with a digital thermometer (Acurite, Lake Geneva, WI, USA) in a modification of the procedure of Corte et al. (1979). Samples were weighed again after roasting (final weight, FW). The IW and FW of each sample were recorded. The percentage of weight loss on cooking (WLC) was calculated by the difference in weight of the whole samples before and after cooking, using the formula: WLC $=(\mathrm{IW}-\mathrm{FW}) / \mathrm{IW}^{*} 100$.

After $30 \mathrm{~min}$ at room temperature, subsamples of each steak sample $(3 \mathrm{~cm}$ length $\mathrm{x} 1 \mathrm{~cm}$ wide $\mathrm{x}$ $1 \mathrm{~cm}$ thick) were collected using a scalpel without compression by cutting along the longitudinal direction of the fiber to assess the shear force. The measurement was adapted from Wheeler et al. (2007), using a TAXT2 texture analyzer (Stable Micro System, Surrey, England) equipped to measure Warner-Bratzler shear force, with calibration to a section at a speed of $20 \mathrm{~cm} \mathrm{~s}^{-1}$. Four readings were taken per sample to calculate the average shear force, which was expressed as kgf.

Sarcomere length measurements were performed on sample portions $(1.5 \mathrm{~cm}$ length $\mathrm{x} 1$ $\mathrm{cm}$ width $\mathrm{x} 0.5 \mathrm{~cm}$ thick) stored in a $50-\mathrm{ml}$ falcon tube containing $10 \%$ formaldehyde solution for 24 h. The formaldehyde solution was subsequently replaced with a $70 \%$ alcohol solution. After $1 \mathrm{~h}$, the $70 \%$ alcohol solution was renewed and each sample remained in storage until processing. When analyzed, samples were removed from the $70 \%$ alcohol solution, embedded in paraffin, and sent to the histology laboratory at UEM where sections were made from the blocks using a microtome. The sections were mounted on slides and examined to measure sarcomere length as described below.

Polylysine was placed on each slide for better fixation of histological sections, which were stained with hematoxylin and eosin (H\&E). Permount was used for the final slide assembly. Images were captured with a microscope coupled to a camera, with a final magnification of $1000 \times$, using QCapture Pro 7 software (QImaging, Surrey, British Columbia, Canada). Image data were stored. Sarcomere length readings were determined using IP WIN32 ImagePro Plus software (Acromag, Wixom, MI, USA) by counting 20 sarcomeres (Figure 1) from 15 random myofibrils, yielding 300 observations per animal, and 9,600 readings for the whole experiment. 
Figure 1. Microphotograph of Longissimus thoracic lumborum muscle fibers, exhibiting A (dark) and I (light) sarcomere bands (Magnification $=1000 \times$ ).

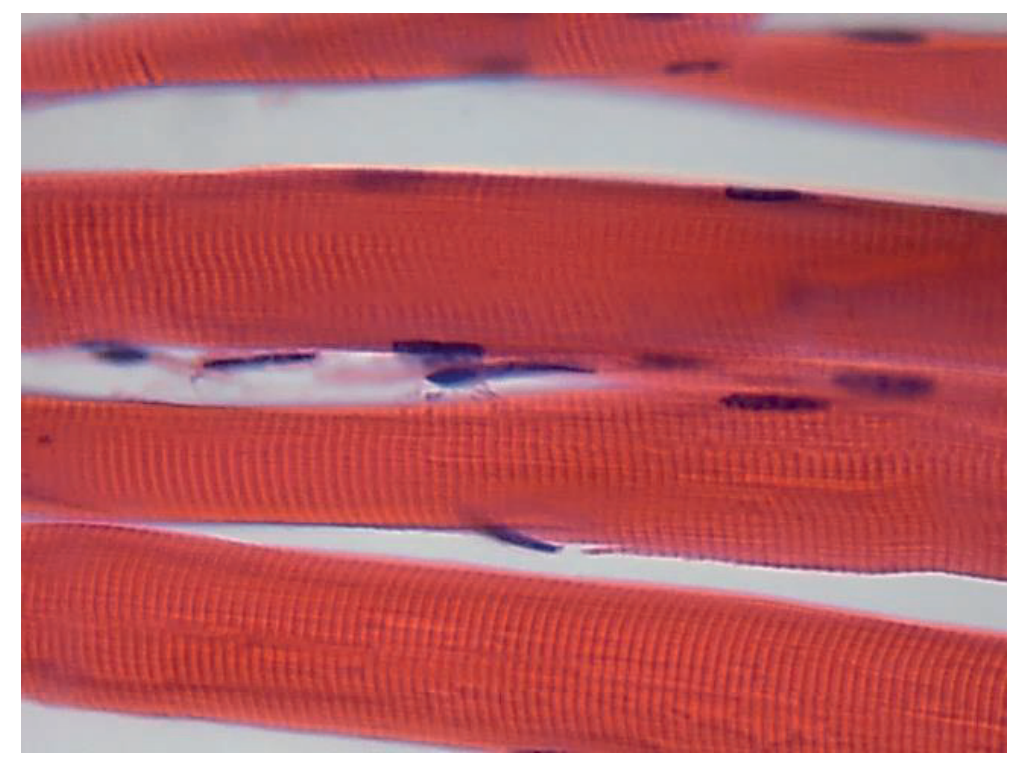

The experiment followed a completely randomized design, corresponding to a $2 \times 4$ factorial, with two cut thicknesses $(2.5$ and $7.5 \mathrm{~cm})$ and four maturation periods $(0,7,14$, and 21 days). There were eight replicates per condition. The analysis regression of the qualitative characteristics versus the maturation period was performed using the Statistical Analysis System (SAS, 2008) with the means of the treatments compared by Tukey's test at the $5 \%$ probability level.

\section{Results and Discussion}

The microbiological analysis results indicated that all samples were handled under sanitary conditions, with counts of psychrotrophic and mesophilic bacteria of $2.18 \times 10^{5}$ colony forming units (CFUs) $\mathrm{g}^{-1}$ and $2.4 \times 10^{5} \mathrm{CFU} \mathrm{g}^{-1}$, respectively. Roça and Serrano (1995) postulated that meat deterioration begins when counts are within the $10^{6}$ $\mathrm{CFU} \mathrm{g}^{-1}$ range, with surface discoloration.
The results of the data analysis of the studied variables are summarized in Tables 1 and 2 as a function of cut thickness and maturation time. Neither factor influenced $\mathrm{pH}$ or WLC (both $\mathrm{P}>$ 0.05). The results revealed the correct handling and external interference control of commercial cuts (larger or steak cuts) with a behavior similar to that of matured, vacuum-packed sirloin commercially available in Brazil.

From a consumer perspective, meat color is the main parameter in the purchase decision. Meats that are redder and lighter-colored are regarded as fresher and are more appealing. The resulting luminosity $\left(\mathrm{L}^{*}\right)$ values presented in Table 1 differed with cut thickness and maturation time $(\mathrm{P}<0.05)$. The 2.5-cm non-matured and 7-day matured cuts were similar to the non-matured and 14-day matured 7.5-cm cuts in their lighter color. The 2.5$\mathrm{cm}$ meat matured for 14 days resembled the $7.5-\mathrm{cm}$ meat matured for 21 days; both and were slightly darker. Regression analysis showed a decrease of $\mathrm{L}^{*}$ of 0.086 per day of maturation, with the meat becoming darker with time (Figure 2). 
Table 1. Means and standard deviations for $\mathrm{pH}$, meat color, and fat color characteristics of the Longissimus thoracic lumborum muscle of Nellore adult cattle, with two cut thicknesses and different maturation periods

\begin{tabular}{|c|c|c|c|c|c|c|}
\hline \multirow{2}{*}{\multicolumn{2}{|c|}{ Parameters }} & \multirow{2}{*}{$\begin{array}{c}\text { Thickness }(\mathrm{cm}) \\
0 \text { days }\end{array}$} & \multicolumn{3}{|c|}{ Maturation (days) } & \\
\hline & & & 7 days & 14 days & 21 days & \\
\hline \multirow{2}{*}{\multicolumn{2}{|c|}{$\mathrm{pH}$}} & 2.5 & $5.66 \mathrm{a} \pm 0.06$ & $5.63 \mathrm{a} \pm 0.09$ & $5.53 \mathrm{a} \pm 0.16$ & $5.54 \mathrm{a} \pm 0.12$ \\
\hline & & 7.5 & $5.64 \mathrm{a} \pm 0.08$ & $5,60 \mathrm{a} \pm 0.27$ & $5.47 \mathrm{a} \pm 0.26$ & $5.47 \mathrm{a} \pm 0.07$ \\
\hline \multirow{6}{*}{$\begin{array}{l}\dot{0} \\
\overline{0} \\
0 \\
\tilde{\Xi} \\
\Sigma\end{array}$} & \multirow{2}{*}{$\mathrm{L}^{*}$} & 2.5 & $46.41 \mathrm{a} \pm 0.33$ & $46.43 \mathrm{a} \pm 0.29$ & $44.44 \mathrm{c} \pm 0.31$ & $45.55 \mathrm{~d} \pm 0.28$ \\
\hline & & 7.5 & $46.37 \mathrm{a} \pm 0.30$ & $47.49 \mathrm{~b} \pm 0.30$ & $45.69 \mathrm{ad} \pm 0.14$ & $44.46 \mathrm{c} \pm 0.29$ \\
\hline & \multirow{2}{*}{$a^{*}$} & 2.5 & $17.31 \mathrm{a} \pm 0.15$ & $17.56 \mathrm{a} \pm 0.23$ & $17.54 \mathrm{a} \pm 0.32$ & $17.51 \mathrm{a} \pm 0.32$ \\
\hline & & 7.5 & $16.36 \mathrm{~b} \pm 0.33$ & $16.46 \mathrm{~b} \pm 0.36$ & $18.56 \mathrm{c} \pm 0.24$ & $19.54 \mathrm{~d} \pm 0.26$ \\
\hline & \multirow{2}{*}{$b^{*}$} & 2.5 & $9.25 \mathrm{a} \pm 0.13$ & $7.55 \mathrm{c} \pm 0.21$ & $6.51 \mathrm{~d} \pm 0.30$ & $6.23 \mathrm{e} \pm 0.22$ \\
\hline & & 7.5 & $8.38 \mathrm{~b} \pm 0.37$ & $6.46 \mathrm{~d} \pm 0.17$ & $6.48 \mathrm{~d} \pm 0.35$ & $6.50 \mathrm{~d} \pm 0.29$ \\
\hline \multirow{4}{*}{ 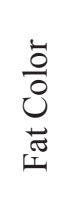 } & \multirow{2}{*}{$a^{*}$} & 2.5 & $12.49 \mathrm{a} \pm 0.29$ & $11.39 \mathrm{~b} \pm 0.31$ & $15.50 \mathrm{~d} \pm 0.27$ & $12.65 \mathrm{a} \pm 0.31$ \\
\hline & & 7.5 & $11.45 b \pm 0.24$ & $7.59 c \pm 0.18$ & $11.31 \mathrm{~b} \pm 0.20$ & $11.49 b \pm 0.24$ \\
\hline & \multirow{2}{*}{$b^{*}$} & 2.5 & $15.25 \mathrm{a} \pm 0.21$ & $15.54 \mathrm{a} \pm 0.30$ & $12.45 b \pm 0.22$ & $12.55 b \pm 0.23$ \\
\hline & & 7.5 & $15.44 \mathrm{a} \pm 0.30$ & $12.56 \mathrm{~b} \pm 0.39$ & $12.41 \mathrm{~b} \pm 0.28$ & $12.43 b \pm 0.20$ \\
\hline
\end{tabular}

Means followed by different lowercase letters in the same row and column differ from each other by Tukey's test at the 5\% level of significance.

Table 2. Means and standard deviations for weight loss on cooking (WLC), shear force (SF), and sarcomere length (SL) of the Longissimus thoracic lumborum of adult Nellore cattle, with two cut thicknesses and different maturation periods

\begin{tabular}{lccccc}
\hline & Thickness & \multicolumn{4}{c}{ Maturation (days) } \\
\cline { 3 - 6 } Parameters & $(\mathrm{cm})$ & 0 days & 7 days & 14 days & 21 days \\
\hline \multirow{2}{*}{ WLC (\%) } & 2.5 & $24.90 \mathrm{a} \pm 0.17$ & $24.40 \mathrm{a} \pm 0.25$ & $23.89 \mathrm{a} \pm 0.23$ & $23.97 \mathrm{a} \pm 0.27$ \\
& 7.5 & $24.01 \mathrm{a} \pm 0.18$ & $23.70 \mathrm{a} \pm 0.04$ & $25.10 \mathrm{a} \pm 0.30$ & $23.08 \mathrm{a} \pm 0.27$ \\
SF (kgf) & 2.5 & $6.36 \mathrm{a} \pm 0.31$ & $6.27 \mathrm{a} \pm 0.27$ & $4.49 \mathrm{c} \pm 0.27$ & $5.44 \mathrm{c} \pm 0.26$ \\
& 7.5 & $7.48 \mathrm{~b} \pm 0.21$ & $4.49 \mathrm{c} \pm 0.27$ & $3.74 \mathrm{~d} \pm 0.45$ & $3.54 \mathrm{~d} \pm 0.39$ \\
SL $(\mu \mathrm{m})$ & 2.5 & $1.54 \mathrm{a} \pm 0.02$ & $1.75 \mathrm{~b} \pm 0.03$ & $1.66 \mathrm{c} \pm 0.02$ & $1.55 \mathrm{a} \pm 0.03$ \\
& 7.5 & $1.55 \mathrm{a} \pm 0.03$ & $1.55 \mathrm{a} \pm 0.03$ & $1.55 \mathrm{a} \pm 0.03$ & $1.55 \mathrm{a} \pm 0.03$ \\
\hline
\end{tabular}

Means followed by different lowercase letters in the same row and column differ from each other by Tukey's test at the 5\% level of significance.

$\mathrm{pH}$ was notable among the variables that altered meat quality, as it influenced the other characteristics. The final $\mathrm{pH}$ values presented in Table 1 demonstrate that there was no influence of pre-slaughter stress on the animals, with slow development of glycolysis that enabled a stable $\mathrm{pH}$ of approximately 5.57. The $\mathrm{pH}$ values were similar to those obtained by Aroeira et al. (2016) after 0 (5.61), 7 (5.54), 14 (5.50), and 21 (5.52) days of maturation. Furthermore, the present values are within the acceptable $\mathrm{pH}$ range of 5.4-5.8 proposed by Mach et al. (2008) as being adequate for shelf life. The $\mathrm{pH}$ behavior of the $\mathrm{pH}$ is illustrated in Figure 2. A regression analysis revealed a $\mathrm{pH}$ decrease of 0.008 units per day of maturation.

The red color intensity $\left(\mathrm{a}^{*}\right)$ differed between maturation periods for the $7.5-\mathrm{cm}$ cut meat $(\mathrm{P}<$ $0.05)$, with a noticeable gradual increase of red 
intensity of 0.872 with a maturation period of 14 days and longer (Figure 2). However, for the $2.5-\mathrm{cm}$ cut, no variation was observed $(\mathrm{P}>0.05)$. Pereira (2002) ascribed this behavior to the myoglobin pigment, which becomes less efficient in oxygen retention in the muscle of animals of more advanced age, with a* values ranging from 18-22.

Figure 2. Regression analysis of the parameters evaluated in Longissimus thoracic lumborum of Nellore adult cattle, with two cut thicknesses and different maturation periods
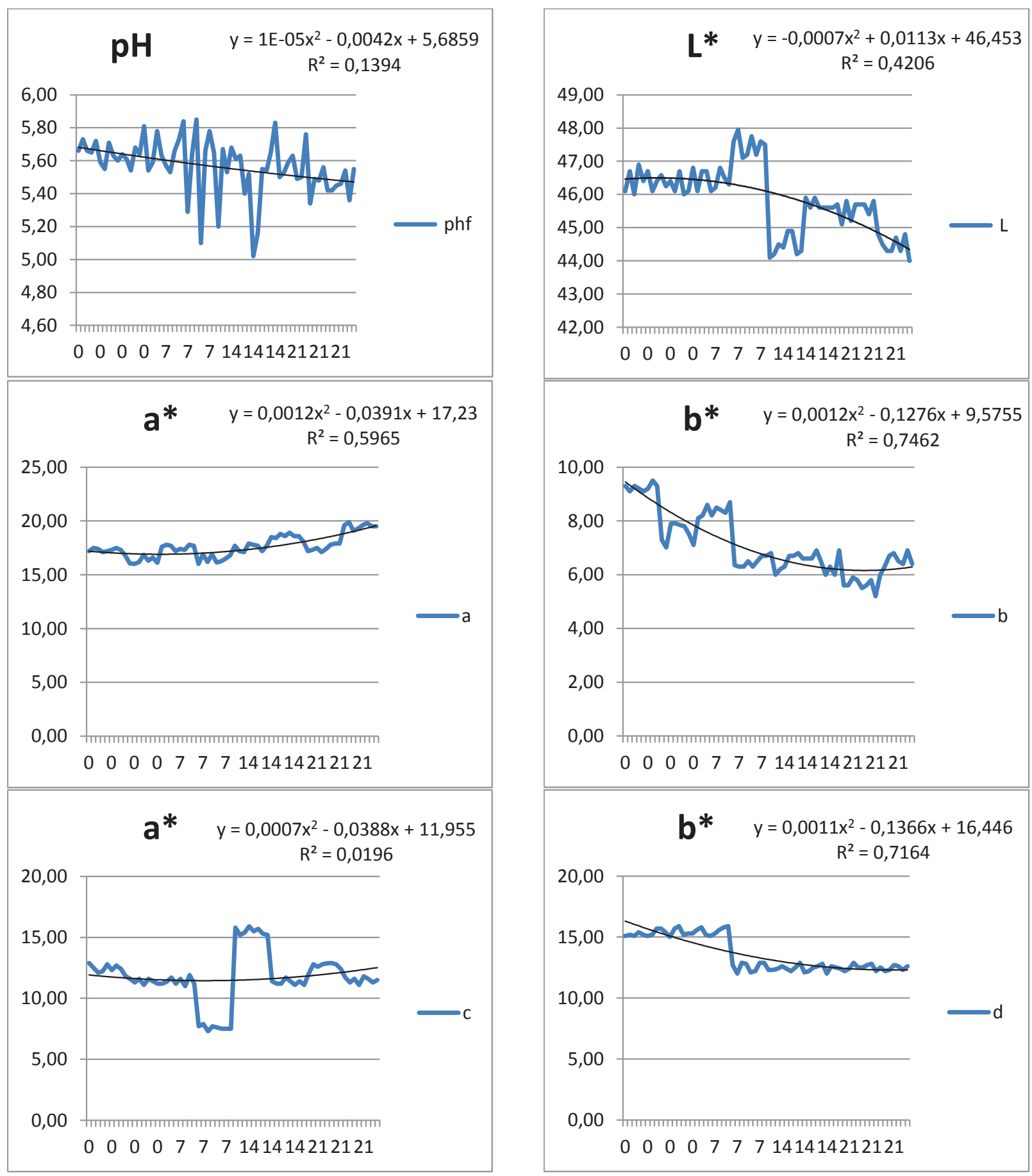

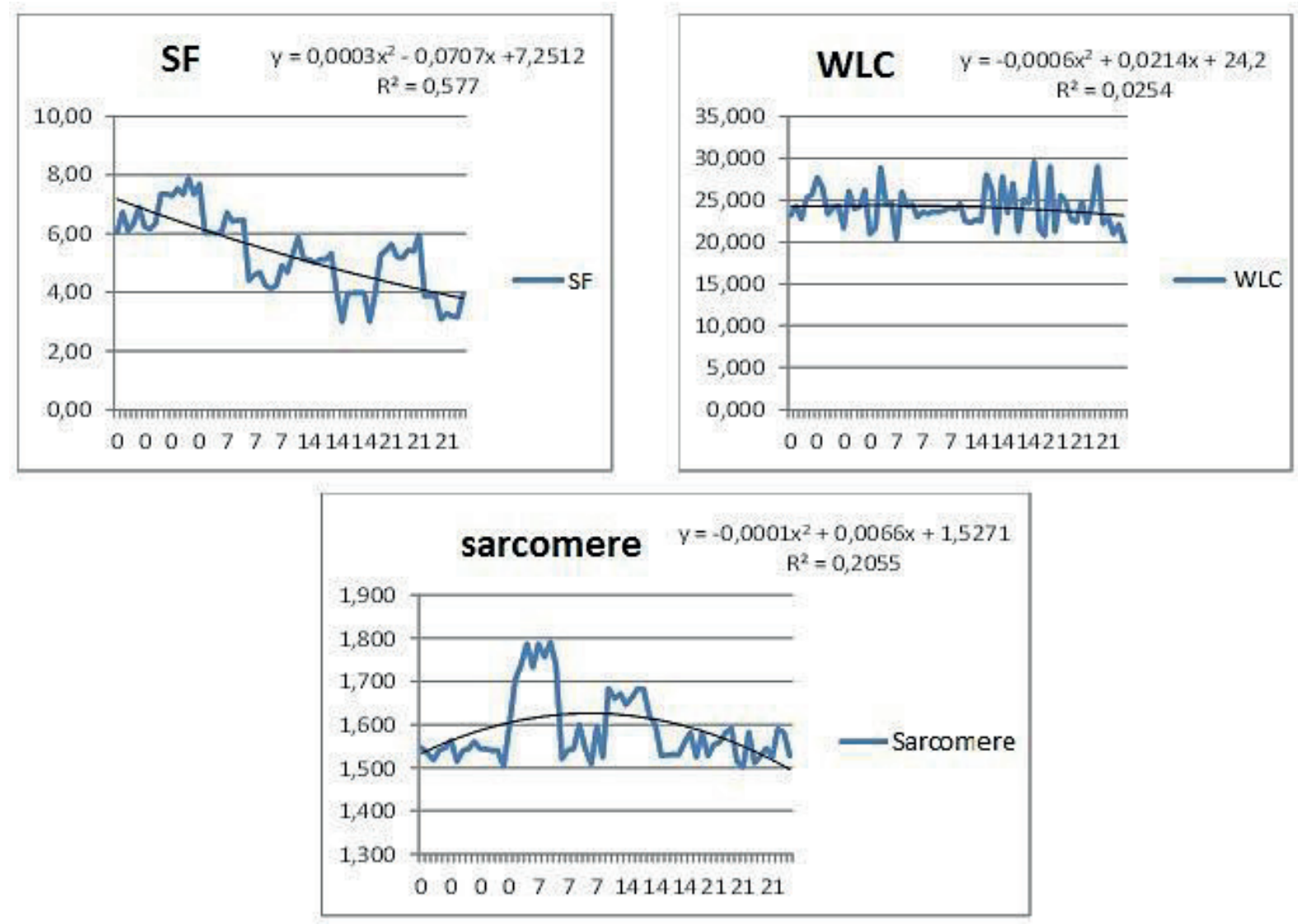

Regarding the yellow color intensity ( $\left.b^{*}\right)$ of the meats, the variation in $b^{*}$ was influenced by both cut thickness and maturation time $(\mathrm{P}<0.05)$, with the $2.5-\mathrm{cm}$ cuts yielding darker colors at time zero and becoming lighter as the maturation period increased. However, the $7.5-\mathrm{cm}$ cuts differed between the non-matured and matured samples (regardless of maturation time), being similar to the $2.5-\mathrm{cm}$ cut at 14 days of maturation. Regression analysis showed a reduction of 0.113 in this parameter with the progression of the maturation period (Figure 2).

Muchenje et al. (2009) classified cattle mean values of 33.2-41.0 for $L^{*}, 11.1-23.6$ for the red color, and 6.1-11.3 for the yellow color, with lower values being characteristic of dark meat and higher values characteristic of lighter meat. Thus, the values obtained in the present study reflect lighter meat, corroborating the findings of Khan et al.
(2016) who reported that enzymatic alterations from the breakdown of certain proteins in matured meat yields a lighter color and shade of red. However, Andrade et al. (2010) reported L*, a*, and b* values at 21 days of maturation of $39.95,19.29$, and 6.02, respectively.

Regarding the meat fat coloration ( $\mathrm{a}^{*}$ and $\mathrm{b}^{*}$ ), the intensity of $\mathrm{a}^{*}$ of the 2.5 -cm cuts after 21 days of maturation resembled that of the non-matured sample, which differed from the 7- and 14-day maturation periods, being lighter at 7 days of maturation $(\mathrm{P}<0.05)$. The $7.5-\mathrm{cm}$ cuts that were matured for 7 days differed from the remaining periods of maturation. The regression analysis showed an increase of 0.601 in this parameter per unit of maturation time across the evaluated meats. The intensity of meat fat $b^{*}$ were similar results from 7 days of maturation period onward for 
both cut thicknesses $(\mathrm{P}>0.05)$. As the maturation period increased, a slight reduction of the values (0.146) resulted in lighter-shaded fat. This could indicate that the meat fat color tends to stabilize throughout the maturation process, and that the red color intensity variation is influenced by the blood exuded upon exposure of the meat to the ambient temperature.

It was possible to identify variations in the behaviors of the parameters. A possible explanation could be that the $2.5 \mathrm{~cm}$ cut represents a smaller contact surface, volume, and concentration of muscular mass than the larger cut $(7.5 \mathrm{~cm})$. In this scenario, the greater area of exposure may have favored and accelerated meat oxygenation as well as increasing enzymatic activity, generating the results observed.

There was no difference in cut thicknesses or maturation periods $(\mathrm{P}>0.05)$ concerning WLC, with a mean value of $24.13 \%$ (Table 2). A WLC reduction of 0.003 per unit time was observed. This result was expected because of the vacuum-packing that maintained meat moisture, and the stabilization and control of temperature needed for the maturation process. A similar WLC average value (24.58\%) was observed by Silva et al. (2014) over maturation periods of up to 14 days, demonstrating the beneficial effect of this methodology. The cattle breed (zebu) may influence this feature. According to Maggioni et al. (2012), Nellore cattle meat exhibits lower weight losses in the preparation for consumption compared to taurine breeds.

The shear force of the meat changed with the maturation period starting at day $0(\mathrm{P}<0.05)$, with a shear force reduction of 0.117 per day (Figure $2)$. The $2.5-\mathrm{cm}$ cuts matured for 14 days yielded better results $(\mathrm{P}>0.05)$ compared to the $2.5-\mathrm{cm}$ cuts matured longer (Table 2). The 7.5-cm cuts matured for 14 days showed a higher tenderness degree than all other maturation periods. The results demonstrate the satisfactory effect of maturation on meat tenderness. The decrease in shear force values from non-matured meat (6.92 kgf, considered tough) to $4.49 \mathrm{kgf}$ after 21 days of maturation (classified as moderately tender) corroborates the findings of Boleman et al. (1997), which classified beef meat tenderness as very tender (2.3-3.6 kgf), moderately tender (4.1-5.4 kgf), and tough (5.9-7.2 kgf).

The mean shear force value observed in the present study (5.2 kgf) reveals a more tender meat when compared to the value of $7.51 \mathrm{kgf}$ after 14 days of maturation reported by Silva et al. (2014), and similarly tender meat compared to Aroeira et al. (2016), who reported shear force values at $0,7,14$, and 21 days of maturation of $6.83,5.71$, 5.4, and $4.88 \mathrm{kgf}$, respectively. Thus, there was an improvement in Nellore cattle meat tenderness induced by maturation. In contrast, Andrade et al. (2010) observed a greater degree of meat tenderness than that described presently $(4.9 \mathrm{kgf}$ at 0 days of maturation, $3.81 \mathrm{kgf}$ at 7 days, and $3.04 \mathrm{kgf}$ at 21 days); the meat became very tender after 7 days of maturation, corroborating the conclusion of Bianchini et al. (2007) that Nellore meat requires a minimum maturation period of 7 days to become tender.

Sarcomere lengths behaved randomly as a function of maturation for the $2.5-\mathrm{cm}$ cuts $(\mathrm{P}<$ $0.05)$, and remained constant for the 7.5-cm cuts $(\mathrm{P}>$ $0.05)$. The 21-day matured and non-matured $2.5-\mathrm{cm}$ cuts exhibited similar sarcomere lengths $(1.54 \mu \mathrm{m})$, and both differed from the lengths at 7 and 14 days of maturation, $1.75 \mu \mathrm{m}$ and $1.66 \mu \mathrm{m}$, respectively $(\mathrm{P}<0.05)$. This behavior at 7 days of maturation may reflect a higher degree of proteolytic enzyme activity with myofibril degradation (BOSCO et al., 2016), with a return to the expected behavior after 21 days of maturation.

The mean sarcomere length value of matured meats obtained in the present study was $1.59 \mu \mathrm{m}$, which is shorter than the $1.97 \mu \mathrm{m}$ reported by Aroeira et al. (2016). However, according to Koohmaraie et al. (2002), sarcomere lengths decrease in the 24hour post mortem period, from $2.24 \mu \mathrm{m}$ at the time 
of rigor mortis to $1.69 \mu \mathrm{m}$ after maturation due to the formation of the actomyosin complex with the overlap of myofilaments.

This behavior may be associated with the fact that the Nellore breed features a lower deposition of intramuscular fat. Bouton et al. (1978) reported that meat with greater fat deposition has longer sarcomere lengths. Thus, the shortening of sarcomeres observed in the present study is related to a greater sarcomere disruption, resulting in greater degradation of myofibril and connective tissue structural proteins, yielding more tender meat as evidenced by the shear force (mean of $5.2 \mathrm{kgf}$ ). The maturation period positively influenced the main variables of shear force, color, and sarcomere length, emphasizing the benefit of the vacuum maturation process on beef quality.

\section{Conclusion}

The Longissimus thoracic lumborum muscle of adult Nellore cattle should be matured as a larger cut for a minimum period of 14 days, as it improves the main qualitative characteristics of the meat, particularly its tenderness.

\section{References}

ANDRADE, P. L.; BRESSAN, M. C.; GAMA, L. T.; GONÇALVES, T. M.; LADEIRAA, M. M.; RAMOS, E. M. Qualidade da carne maturada de bovinos Red Norte e Nelore. Revista Brasileira de Zootecnia, Viçosa, MG, v. 39, n. 8, p.1791-1800, 2010.

AROEIRA, C. N.; TORRES FILHO, R. A.; FONTES, P. R.; GOMIDE, L. A.; RAMOS, A. L.; LADEIRA, M. M.; RAMOS, E. M. Freezing, thawing and aging effects on beef tenderness from Bos indicus and Bos Taurus cattle. Meat Science, Barking, v. 116, n. 6, p. 118-125, jun. 2016.

ASSOCIAÇÃO BRASILEIRA DA INDÚSTRIA EXPORTADORA DE CARNE - ABIEC. Exportações de carne bovina do Brasil de janeiro a dezembro de 2015. São Paulo: CDN Comunicação, 2015. Disponível em: $<$ http://www.abiec.com.br/41_exportacao_ano.asp $>$. Acesso em: 23 abr. 2016.
BIANCHINI, W.; SILVEIA, A. C.; JORGE, A. M.; ARRIGONI, M. D. B.; MARTINS, C. L.; RODRIGUES, E.; HADLICH, J. C.; ANDRIGHETTO, C. Efeito do grupo genético sobre as características de carcaça e maciez da carne fresca e maturada de bovinos superprecoces. Revista Brasileira de Zootecnia, Viçosa, MG, v. 36, n. 6, p. 2109-2117, 2007. Suplemento.

BOLEMAN, S. J.; BOLEMAN, S. L.; MILLER, R. K.; TAYLOR, J. F.; CRUZ, H. R.; WHEELER, T. L.; KOOHMARAIE, M.; SHACKELFORD, S. D.; MILLER, M. F.; OESTE, R. L.; JOHNSON, D. D.; SAVELL, J. W. Consumer evaluation of beef of know categories of tenderness. Journal of Animal Science, Savoy, v. 75, n. 6, p. 1521-1524, 1997.

BOSCO, D. M. S.; ANDRIGHETTO, C.; LUZ, P. A. C.; POIATTI, M. L.; JORGE, A. M.; FRANCISCO, C. L.; TIVELIN, G. A.; VAZ, R. F.; SANTOS, J. M. F. Qualidade da carne bovina maturada e tenderizada comercializada na região de dracena, SP. Boletim Indústria Animal, Nova Odessa, v. 73, n. 4, p. 304-309, 2016.

BOUTON, P. E.; FORD, A. L.; HARRIS, P. V.; SHORTHOSE, W. R.; RATCLIFF, D.; MORGAN, J. H. L. Influence of animal age on the tenderness of beef: muscle differences. Meat Science, Barking, v. 2, n. 4, p. 301-311, 1978.

BRASIL. Ministério da Agricultura. Regulamento da inspeção industrial e sanitária de produtos de origem animal. Brasília: Ministério da Agricultura, 1952. 159 p.

CAVALLI-SFORZA, L. Biometrie: Grundzüge biologischmedizinische Statistic (Biometria: fundamentos de estatística viológica-médica). Stuttgart: Gustav Fisher, 1974. p. 201-4.

CORTE, O. O.; FELÍCIO, P. E. de; CIA, G. Sistematização da avaliação final de bovinos e bubalinos. III. Qualidade da carne. Boletim Técnico do CTC, Campinas, v. 6, n. 3, p. $67-76,1979$.

KHAN, M.; JUNG, S.; NAN, K. C.; JO, C. Postmortem aging of beef with a special reference to the dry aging. Korean Journal Food Science of Animal, HigashiHiroshima, v. 36, n. 2, p. 159-169, 2016.

KOOHMARAIE, M. The role of endogenous proteases in meat tenderness. In: PROCEEDINGS OF ANNUAL RECIPROCAL MEAT CONFERENCE, 41., 1989, Wyoming. Proceedings... Wyoming: [s.n.], 1989. p. 8999.

KOOHMARAIE, M.; KENT, M. P.; SHACKELFORD, S. D.; WHEELER T. L. Meat tenderness and muscle growth: is there any relationship? Meat Science, Barking, v. 62, n. 4, p. 345-352, 2002. 
KRINCHEV, A. F. B.; BOLFE, F. C.; PINTO, A. B. R.; GIANGARELI, B. L.; VERO, J. G.; ROGEL, C. P.; FAGAN, P.; BRIDI, A. M. Avaliação microbiológica da carne maturada de novilhos Nelore e cruza Angus x Nelore. In: CONGRESSO BRASILEIRO DE ZOOTECNIA. ZOOTECNIA DO FUTURO: PRODUÇÃO ANIMAL SUSTENTÁVEL, 23., 2013, Foz do Iguaçu. Anais... Foz do Iguaçu: ABZ, 2013. p. 3.

MACH, N.; BACH, A.; VELARDE, A.; DEVANT, M. Association between animal, transportation, slaughterhouse practices, and meat $\mathrm{pH}$ in beef. Meat Science, v. 78, n. 3, p. 232-238, 2008.

MAGGIONI, D.; PRADO, I. N.; ZAWADZKI, F.; VALERO, M. V.; MARQUES, J. A.; BRIDI, A. M.; MOLETTA, J. L.; ABRAHÃO, J. J. S. Grupos genéticos e graus de acabamento sobre qualidade da carne de bovinos. Semina: Ciências Agrárias, Londrina, v. 33, n. 1, p. 391-402, jan./mar. 2012.

MUCHENJE, V.; DZAMA, B. K.; CHIMONYO, M.; STRYDOM, P. E.; HUGO, A.; RAATS, J. G. Some biochemical aspects pertaining to beef eating quality and consumer health: a review. Food Chemistry, South Africa, v. 112, n. 112, p. 279-289, 2009.

PARDI, M. C.; SANTOS, I. F.; SOUZA, E. R.; PARDI, H. S. Ciência, higiene e tecnologia da carne. 2. ed. Goiânia: UFG, 2001. 623 p.
PEREIRA, A. S. C. Qualidade da carne de bovinos Nelore (Bos taurus indicus) suplementados com vitamina E. 2002. Dissertação (Mestrado em Zootecnia) - Universidade de São Paulo, Pirassununga.

ROÇA, R. O.; SERRANO, A. M. Abate de bovinos: alterações microbianas da carcaça. Higiene Alimentar, São Paulo, v. 9, n. 35, p. 8-13, 1995.

ROMEIRO, R. S. Métodos em bacteriologia de plantas. Viçosa, MG: UFV, 2001. 279 p.

SILVA, B.; POLETI, M. D.; MONCAU, C. T.; ROSA, A. F.; SILVA, S. L.; BALIEIRO, J. C. C. Características endócrinas, metabólicas e indicadoras da qualidade da carne em bovinos Nelore castrados e não castrados. Ciência Rural, Santa Maria, v. 44, n. 5, p. 904-910, 2014.

STATISTICAL ANALYSIS SYSTEM INSTITUTE SAS. User's Guide: Statistics. Version 9.2. Cary: SAS Inst., 2008. CD-ROM.

VANDERZANT, C; SPLITTSTOESSER, D. F. Compendium of methods for the microbiological examination of foods. $3^{\text {th }}$ ed. Washington: APHA, 1992. $1219 \mathrm{p}$.

WHEELER, T. L.; SCHACKELFORD, S. D.; KOOHMARIE, M. Beef longissimus slice shear force measurement among steak locations and institutions. Journal Animal Science, Champaign, v. 85, n. 9, p. 22832289, 2007. 
